\title{
HIGH-TECHNOLOGY INVESTMENTS AS A DRIVER OF RURAL PRODUCTIVITY
}

\author{
Tetiana Mayorova1 ${ }^{1}$, Zbigniew Domżal ${ }^{2}$, Iuliia Gernego ${ }^{3}$, *Oleksandr Dyba ${ }^{4}$ \\ ${ }^{1}$ Dr.Sc., Professor SHEE "Kyiv national economic university named after V. Hetmana", \\ 54/1 Peremohy Ave, Kyiv, 03057, Ukraine,e-mail: mayorova_kneu@ukr.net \\ ${ }^{2}$ Dr.hab., Professor nadz. Uczelnia Nauk Społecznych, 21 Kamińskiego str., Lódż, 90-229, \\ Poland,e-mail: rektorat@uns.lodz.pl \\ ${ }^{3}$ Ph. D., SHEE “Kyiv national economic university named after V. Hetmana”, 54/1 \\ Peremohy Ave, Kyiv,03057, Ukraine, Tel.+380962218313, e-mail: IuliiaGern@ukr.net \\ ${ }^{4}$ Dr.Sc., Associate Professor SHEE "Kyiv national economic university named after \\ V. Hetmana”, 54/1 Peremohy Ave, Kyiv, 03057,Ukraine, e-mail: dyba_m@ukr.net
}

Received 0501 2019; accepted 25032019

One of the greatest challenges for global society is food demand increase that causes the necessity to enable rural productivity growth by automation. Therefore, the research problem lays upon disclosing the high technology-transfer potential as a driver of rural productivity increase. The paper aims to provide evidence on rural productivity under high-tech investment boost. The study is performed through the rural investment's trends reproduction and emerging technologies analysis, considering high-tech opportunities in developed European countries. The results section represents findings to determine the current potential to strengthen automation in rural areas. The rural areas require re-evaluating available high-tech potential within national and regional rural development strategies, implementing scenarios for emerging technologies implementation by rural business.

Keywords: high-technologies, innovation, investment, rural business, rural development.

JEL Codes: G17, O13, O32, R00, R51.

\section{Introduction}

Despite rural areas are inhabited by $25 \%$ of global population, they play an important role under food demand increase (A framework..., 2018; Valin, Sands and Nelson, 2014). A number of studies suggest that global population is expected to increase by $80 \%$ by 2050 (World Urbanization..., 2014). The rural production has to rise by 50-70\% (World Economic..., 2018). The additional annual rural investments are expected to be $\$ 83$ bln for developing countries (A framework..., 2018).

Rural business employs $40 \%$ of the global population (AgFunder, 2017) and contributes more than $30 \%$ of developing countries GDP (Brooks, 2014). However, the demand for rural workforce does not exceed 2-3\% due to the automation that enables productivity growth in developed economies. According to the McKinsey

Copyright (C) 2019 The Authors. Published by Vytautas Magnus University, Lithuanian Institute of Agrarian Economics. This is an open access article distributed under the terms of the Creative Commons Attribution NonCommercial 4.0 (CC BY-NC 4.0) license, which permits unrestricted use, distribution, and reproduction in any medium, provided the original author and source are credited. The material cannot be used for commercial purposes. 
revision, automation tends to displace significant share of existing rural jobs and create new ones by 2030 (Manyika, Lund, Chui, 2017).

A number of studies have found an association between rural areas investment attractiveness and technological progress (Lietuvos..., 2017; Naldia, Nilssonb and Wixe, 2015). Evidence suggests that despite urbanization tendencies, the poorest countries GDP decline is due to the luck of rural investments (Glasmeier, 2017; Timmer, 2008).

Urban areas attract more investments than rural ones owing to automation (Dobbs, 2011). The knowledge-based economy presents a necessity for the worldwide delivery of high technologies, enabled by investing (Statistical..., 2013; Jekabsone and Skribane, 2018). However, rural area remains the least digitized (AgFunder, 2017; Philipa, Cottrilla and Ashmore, 2017). Thus, rural productivity growth calls for investors, which support high-tech (Boserup, 2017).

Considering recent global tendencies of social and economic development, it is important to boost high-tech investments in rural areas (Plotnikova, 2015). Despite a conceptual theoretical framework of rural investments (Blank, 2001; Chuhno, 2007), several questions remain unanswered.

The scientific problem of this article lays upon the question if rural investments with high technology-transfer potential represent a driver of productivity increase and result in social and economic goals achievement. The hypothesis of the paper remains based on complex view to the issue, concerning the impact of high-tech investors on rural area productivity.

The current paper aims to provide empirical and theoretical evidence for the claim that rural productivity is driven by high-tech investment boost.

The object of the research is automation that is boosting social and economic prospects of rural areas. The subject is high-tech investment, contributing to the rural productivity.

The research methodology is based on foreign and Ukrainian scientific literature and statistical data analysis (within the last ten years) to show a link between high-tech investments and rural area development. The primary data of international and Ukrainian rural and investment reports within the last five years are reproduced to confirm appropriate social and economic trends. Particularly, capital investments trends are provided, using the methods of economic and mathematic modelling and dynamics.

A combination of quantitative and qualitative approaches was used in the emerging technologies analysis. This provides robust evidence for rural areas investments with high technology-transfer potential.

The work is organized as follows:

- in further section, a theoretical framework based on high technologies and rural investments is proposed;

provided;

then, trends of rural productivity and high-tech investments are options for high-tech rural investments increase are examined. 
The study is a part of research cycle on sustainable development and high-tech investments. The practical implication is that results can be used within rural and investment activity strategies.

\section{Main theoretical assumptions of the research}

\subsection{Rural productivity driven by high-tech}

Recent trends of social and economic development in a high-tech era have heightened the need for living standards improvement. Based on these circumstances, the national well-being depends on the improvements in industrial and rural areas, concerning their productivity (Jorgenson, 1991).

Theoretical evidence suggests that productivity is a measure of performance, namely the ratio of outputs to inputs, where larger value of the ratio is associated with more conductive performance (Coelli, Rao, O'Donnell and Battese, 2005). Productivity measures indicate the effectiveness of human, physical and technical resources use. Another problem is productivity valuation, which is calculated owing to the production contribution to the economic growth as Gross Value Added (Productivity measured..., 2017). One of the greatest productivity challenges is its multifactor nature. The production function is concerned as follows:

$$
Q(t)=\operatorname{MFP}(t) * f[K(t), L(t)]
$$

where: $Q(t)$ - real output; $M F P(t)$ - index of multifactor productivity or technological progress; $K(t)$ - real capital input; $L(t)$-real labour input. namely:

Such relationship is also recognized as the tendencies of growth model,

$$
\% Q(\text { growth })=\% M F P(\text { growth })+s k \% K(\text { growth })+s f \% L(\text { growth }),
$$

where: sk and sf are the output elasticity of factor inputs (Munnell, 1990).

Traditionally, rural area productivity is driven by capital, including finance, skills, infrastructure and labour. However, digital changes create an opportunity to restructure rural economies as well as improve rural productivity. Thus, in light of recent events, it is difficult to ignore high-tech investments that determine rural productivity.

\subsection{High-technology investments in rural area}

The investment priorities in rural areas are changing due to the external conditioning variables, including land and capital markets, technology and locationspecific variables, which influence the capabilities to invest (Investment priorities..., 2006). Although terms "rural" and "agriculture" are not considered in the same way (Agricultural policies..., 2017), rural investments are considered in broad terms, including: 
- $\quad$ agricultural investments;

- $\quad$ investments in non-agricultural activities;

- $\quad$ rural area development investments (Hohfeld, Waibel, 2013).

Thus, the high-tech expenditures are invested to generate additional rural income in the next period (Leicht, Jenkins, 2017). However, there is a measure of high-tech investments requirements and limitations (Rajn, Preeti, 2016; Trigubovich, 2017) (Table 1).

Table 1. High-tech investments requirements and limitations in rural areas

\begin{tabular}{|l|l|}
\hline \multicolumn{1}{|c|}{ Requirements } & \multicolumn{1}{c|}{ Limitations } \\
\hline High technologies competitiveness & Rapid global technological changes \\
\hline $\begin{array}{l}\text { Flexibility in acquiring information and } \\
\text { investment activity }\end{array}$ & Investment market changes \\
\hline Proper allocation of high-tech funds & Limited resources \\
\hline Strategic background & Lack of team competence \\
\hline Technology management & Lack of innovative culture \\
\hline
\end{tabular}

Therefore, the attention is paid to high-tech manifestations, which enable rural areas productivity increase.

\section{Results of the research and discussion}

3.1. Factors of rural infrastructure development in Central and Eastern Europe

Traditionally, competitive rural infrastructure in Central and Eastern Europe is influenced by several factors, namely:

- favourable climate and weather conditions, fertile lands $(32.5 \mathrm{mln}$ ha of arable land, including $19.4 \mathrm{mln}$ ha of black-earth soil (chernozem) that makes $1 / 3$ of global reserves in Ukraine);

- $\quad$ low-cost and high-quality labour force;

- markets neighbourhood, including Europe, Africa and the Middle East (Vedenja..., 2018; Plotnikova, 2015).

However, rural infrastructure requires investments, which provide basics to improve welfare, life and business quality.

\subsection{Rural productivity and investments in Poland and Ukraine}

Rural areas contribute nearly $13 \%$ of Ukrainian and 3\% of Polish GDP (Vedenja..., 2018). Revenues from rural exports increased by $16.3 \%$ in Ukraine and $8.3 \%$ in Poland in 2017 to 2016 . The proceeds from the rural export from Ukraine to the EU (5.52 bln euros) increased by 27\% in 2017 to 2016 (What..., 2018; Rocznik..., 2017). Thus, rural productivity increase involves additional investments (Figure 1). 

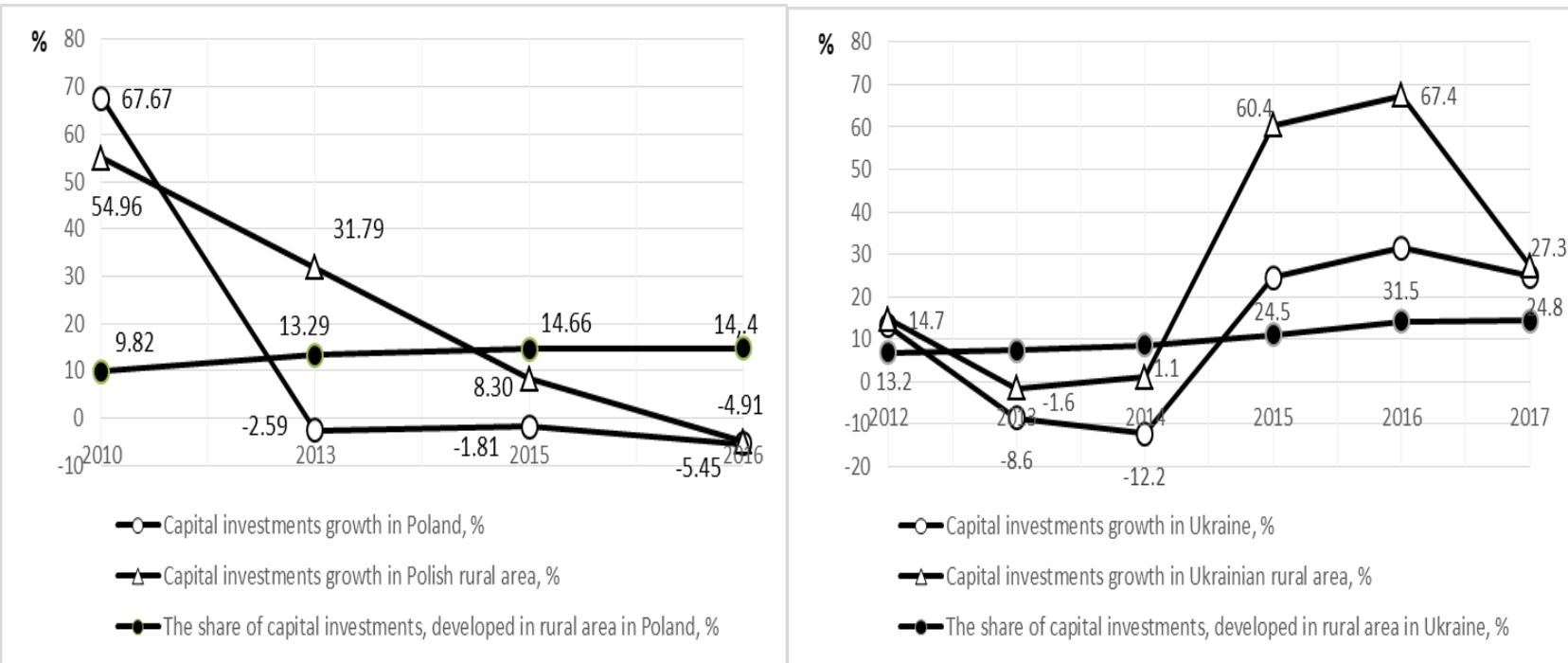

Figure 1. Trends of rural investments in Poland and Ukraine

Data in the Figure reveal that the tendencies of rural capital investments growth are higher than national trends. Additionally, 30\% of rural investments in Poland support machinery and technical equipment. However, the potential of rural investments is not fully used due to the automation luck in both countries.

\subsection{Rural high-tech capacity and investments in developed economies}

The EU rural development policy is funded within 118 rural development programmes, which provide a set of financial tools for high-tech investments in rural areas (Rural..., 2018) (Figure 2).

\begin{tabular}{|c|c|}
\hline $\begin{array}{l}\quad \text { Flexible rural development forms } \\
\text { Rural digital accelerator } \\
\text { Academy on Tour (Belgium) } \\
\text { Short Food Suppy Chain Masterclass (the Netherlands) } \\
\text { AgriEnt Business Accelerator (Greece) } \\
\text { Community broadband } \\
\text { North-Western Kuhmo Village Optical Fibre } \\
\text { Cooperative (Finland) } \\
\text { Molenwaard Civil Society Broadband (the Netherlands) } \\
\text { Rural digital hub } \\
\text { Cocotte Numérique (France) } \\
\text { \#hellodigital (Scotland) } \\
\text { Ludgate Hub (Ireland) }\end{array}$ & $\begin{array}{l}\text { Multiple funding sources in } \\
\text { Europe } \\
\text { European regional } \\
\text { development fund / Cohesion } \\
\text { fund } \\
\text { European agricultural fund for } \\
\text { rural development } \\
\text { European social fund } \\
\text { National rural development } \\
\text { rural development programs }\end{array}$ \\
\hline
\end{tabular}

Figure 2. High-tech opportunities in rural Europe 
Figure 2 presents a set of opportunities to attract financial resources in developed European economies, considering high-tech as the target for rural business development.

\subsection{Rural technologies global potential in a time of automation}

A wide range of flexible technologies is transforming the world around us (Innovation..., 2018). The power of technologies helps to transform rural productivity (Figure 3).

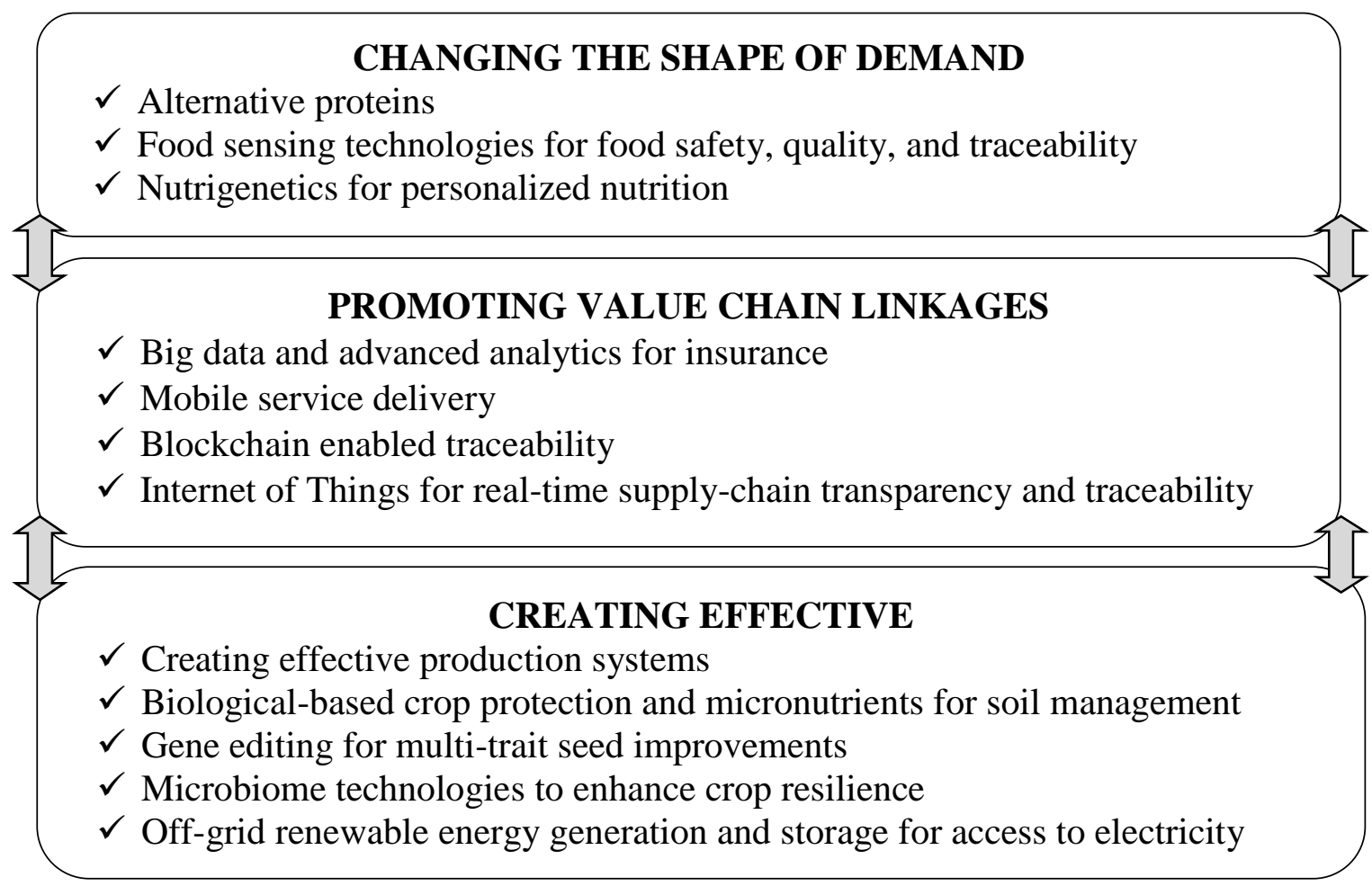

Figure 3. Emerging rural business technological opportunities

Figure 3 reveals main technology applications influence on the shape of demand, supply chains and transparency, quality and quantity of products. Thus, emerging technologies have the potential to drive rapid progress in rural area globally.

\section{Conclusions}

1. The first set of analyses examines the evidence on significant benefits for rural business, caused by automation technologies. The correlation between high-tech influences and rural productivity is tested using production function, considering the priority of automation strengthening. A prospect for further researches is technical potential analysis to be automated by adapting currently demonstrated technologies in rural area both in developed and developing countries.

2. The research provides insights into the high-tech rural investment's limitations, considering their role in social and economic development. Thus, that 
shows the requirement to re-evaluate high-tech potential within national and regional rural development strategies, rural business scenarios adoption.

3. Central and Eastern European experiences show that despite the rural investments increase in Poland and Ukraine (almost twice as much as general capital investment growth in 2017 to 2014), investment potential is not fully adapted. The decision is to implement emerging technologies which have the potential to involve investors and drive rapid progress in rural area.

4. High-tech opportunities in Europe are considered as an important feature of rural investments increase. Thus, the global rural community faces the urgency for emerging technologies implementation in rural areas worldwide.

\section{References}

A framework for rural development. Rural 3.0. (2018). - Paris: OECD. 27 p.

AgFunder (2017). AgriFood Tech. - https://research.agfunder.com/2017/AgFunder-AgrifoodTech-Investing-Report-2017.pdf [12 01 2018]

Agricultural policies and rural development. (2017). OECD. https://www.oecd.org/agriculture/44561502.pdf [06 15 2018].

Blank, I. (2001). Osnovy investycijnoho menedzhmentu. - Kyiv: El"ha-N, Nika-Centr. 536 p.

Boserup, E. (2017). The conditions of agricultural growth. The Economics of Agrarian Change under Population Pressure. - London: GEORGE ALLEN \& UNWIN LTD. 108 p.

Chuhno, A. (2007). Hospodars"kyj mexanizm ta shlyaxy joho vdoskonalennya na suchasnomu etapi // Ekonomika Ukrayiny. No. 3: 60-67.

Coelli, T., Rao, D., O'Donnell, C., Battese, G. (2005). An Introduction to Efficiency and Productivity Analysis. - New York: Springer Science. 345 p.

Dobbs, R. (2011). Urban world: Mapping the economic power of cities. - Washington: McKinsey. 62 p.

Glasmeier, A. (2017). The High-Tech Potential: economic development in rural America. New York: Routlage. 216 p.

Hohfeld, L., Waibel, H. (2013). Investments of Rural Households in Northeast Thailand and the Future of Small-Scale Farming // Quarterly Journal of International Agriculture. No. 3: 217-236

Innovation with a Purpose: The role of technology innovation in accelerating food systems transformation. (2018). - http://www3.weforum.org/docs/WEF_Innovation_with_a_Purpose_VFreduced.pdf [12 012018 ]

Investment Priorities for Rural Development. (2006). Edinburgh: OECD. 8 p.

Jekabsone, S., Skribane, I. (2018). Investments in Latvia // Regional Formation and Development Studies. No. 1(24): 35-43.

Leicht, K., Jenkins J. (2017). State investments in high-technology job growth // Social Science Research. Vol. 65: 30-46

Lietuvos statistikos metraštyje. (2017). - Vilnus: Lietuvos statistikos departamentas. 673 p. https://osp.stat.gov.lt/services-portlet/pub-edition-file?id=26780 [11 16 2018].

Manyika, J., Lund, S., Chui, M. (2017). Jobs lost, jobs gained: workforce transitions in a time of automation. - New York: McKinsey. 160 p.

Munnell, A. (1990). Why has productivity growth declined? Productivity and public investment // New England Economic Review. No. 1: 3-22.

Naldia, L., Nilssonb, P., Westlunded, H., Wixe S. (2015). What is smart rural development? // Journal of Rural Studies. Vol. 40: 90-101 
Philipa, L., Cottrilla, C., Farringtona, J., Williamsb, F., Ashmore, F. (2017). The digital divide: Patterns, policy and scenarios for connecting the 'final few' in rural communities across // Great Britain Journal of Rural Studies. Vol. 54: 386-398.

Plotnikova, M. (2015). Conceptual basis for Ukrainian rural development // Regional Formation and Development Studies. No. 3 (17): 134-144.

Productivity measured by Gross Value Added (GVA). (2017). UK. https://assets.publishing.service.gov.uk/government/uploads/system/uploads/attachment_data/file/6 76077/Productivity_2016_with_industry_data_-_final.pdf [12 01 2018]

Rajni, S., Preeti, H. (2016). Strategic financial management. Delhi: PHI. 434 p.

Rocznik statystyczny rolnictwa. (2017). -Warszawa: Urzęd Statystyczny. 495 s.

Rural business. (2018). - - https://enrd.ec.europa.eu/enrd-thematic-work/smart-andcompetitive-rural-areas/rural-businesses_en [14 01 2018]

Statistical Digest of Rural England. Report. (2013). - London: Defra. 118 p.

Trigubovich, L. (2017). Napravleniia razvitiia innovatsionnoi sfery Respubliki Belarus. Minsk: Institut sistemnykh issledovanyi v APK NAN Belarusi. 235 p.

Valin, H., Sands, R., Nelson, G (2014) The future of food demand: understanding differences in global economic models // Agricultural economics. Vol.45: 51-67
Vedenja
ahrobiznesu
$\mathrm{v} \quad$ Ukraini.
(2018).

http://www.ucab.ua/ua/doing_agribusiness/umovi_vedennya_agrobiznesu/derzhavna [12 012018$]$

What will be with land reform? - http://www.uagra.com.ua/analytics/articles/shcho-bude-zzemelnoyu-reformoyu [12 012018$]$

World Economic Situation and Prospects. (2018). - New York: UN, 207 p.

World Urbanization Prospects. The 2014 Revision Highlights. (2014). Department of Economic and Social Affairs. - New York: United Nations. 32 p.

\title{
INVESTICIJOS İ AUKŠTĄSIAS TECHNOLOGIJAS KAIP KAIMO PRODUKTYVUMO VAROMOJI JËGA
}

\author{
Tetiana Mayorova ${ }^{1}$, Zbigniew Domżal ${ }^{2}$, Iuliia Gernego ${ }^{3}$, *Oleksandr Dyba ${ }^{4}$ \\ 1,3,4 Vadimo Hetmano Kyivo nacionalinis ekonomikos universitetas, ${ }^{2}$ Uczelnia Nauk Społecznych
}

Pateikta 201901 05; priimta 20190325

\section{Santrauka}

Vienas didžiausiu iššūkiu pasaulio bendruomenei yra padidèjęs maisto poreikis, dèl kurio būtina skatinti kaimo produktyvumo augumą diegiant automatizuotus procesus. Atsižvelgiant $\mathfrak{i}$ tokị poreikį, tyrimo problema siekiama atskleisti aukštųjų technologijų perdavimo potencialą kaip kaimo produktyvumo augimo variklį. Darbe siekiama pateikti kaimo produktyvumo pasikeitimo ịrodymų esant didelėms investicijoms $\mathfrak{i}$ aukštąsias technologijas. Tyrimas atliktas atkuriant investicijų $\mathfrak{i}$ kaimą tendencijas ir atliekant technologijų analizę, atsižvelgus $\mathfrak{i}$ aukštujų technologijų galimybes išsivysčiusiose Europos šalyse. Rezultatų dalyje pateikiami gauti rezultatai, padedantys nustatyti esamą potencialą stiprinant automatizavimą kaimo vietovėse. Nustatyta, kad kaimo vietovių atveju būtina peržiūrèti turimą aukštụjų technologijų potencialą nacionalinių ir regioninių kaimo plètros strategiju kontekste, igyvendinant scenarijus, kai naujas technologijas diegia kaimo verslas.

Raktiniai žodžiai: aukštosios technologijos, inovacija, investicijos, kaimo verslas, kaimo plètra.

JEL kodai: L31, O13, O18, R00, R51.

\footnotetext{
* Autorius pasiteirauti
} 